\title{
First evidence of Candidatus Neoehrlichia mikurensis in Hungary
}

\author{
Sándor Hornok ${ }^{*}$, Marina L Meli $^{2}$ Enikő Gönczi ${ }^{2}$ and Regina Hofmann-Lehmann²
}

\begin{abstract}
Altogether 2004 Ixodes ricinus ticks, from 37 places in Hungary, were analysed in pools with a recently developed multiplex real-time PCR for the presence of Candidatus Neoehrlichia mikurensis and for other representatives of the genus. $\mathrm{Ca}$. Neoehrlichia mikurensis was identified in nine sampling sites, indicating three separated endemic regions along the borders of Hungary. In addition, results of samples from seven places (except for the western part of the country) were positive in the genus-specific (Ca. Neoehrlichia sp.) PCR, but were negative for Ca. Neoehrlichia mikurensis.
\end{abstract}

Keywords: Tick-borne diseases, Zoonosis, Epidemiology

\section{Letter}

Candidatus Neoehrlichia mikurensis is a Gram-negative, coccoid bacterium in the family Anaplasmataceae that infects endothelial cells of its host [1]. In Europe it is transmitted by Ixodes ricinus. Larvae and nymphs of this tick species frequently suck blood on rodents, which are the most important wild animal reservoirs of $\mathrm{Ca}$. Neoehrlichia mikurensis [2,3]. Subsequently, if nymphs or adults of $I$. ricinus will suck blood on humans or domestic animals, these hosts may become infected. $\mathrm{Ca}$. Neoehrlichia mikurensis was isolated several times from diseased humans, justifying its zoonotic nature [4]. Among domestic animals the susceptibility of dogs was demonstrated [5].

In Europe the history of $\mathrm{Ca}$. Neoehrlichia mikurensis dates back only 15 years. First indications of a related (Ehrlichia-like) sequence became available in 1998 from The Netherlands [6], then later (2003-2006) from Italy $[5,7]$. More recent studies showed the presence of this agent in several Western and two Central European countries: Switzerland, Belgium, Germany, Sweden, Denmark, the Czech Republic and Slovakia [8]. Even in Western Europe some countries, like the UK, appear to be exempt of $\mathrm{Ca}$. Neoehrlichia mikurensis [2]. However, relevant

\footnotetext{
* Correspondence: Hornok.Sandor@aotk.szie.hu

${ }^{1}$ Department of Parasitology and Zoology, Faculty of Veterinary Science, Szent István University, Budapest 1078, Hungary

Full list of author information is available at the end of the article
}

information is lacking from most parts of Central-Eastern Europe.

For this reason it was decided to screen large numbers of $I$. ricinus ticks for the presence of $\mathrm{Ca}$. Neoehrlichia mikurensis with a recently developed, highly sensitive molecular method [8].

DNA samples of 2004 I. ricinus ticks were used in this study. These ticks were collected from the vegetation by the dragging-flagging method from March to July in 2007, at 37 locations in Hungary (Figure 1). A minimum of 40 ticks were collected from each location. The sampling focused on the southern and on the northern borders of Hungary, to monitor any epidemiological connections of tick-borne agents with neighbouring countries. Ticks were stored in $70 \%$ ethanol and pooled prior to DNA extraction according to places of collection.

DNA extraction from tick pools was done by the MagNA Pure LC total nucleic acid isolation kit (Roche Diagnostics, Rotkreuz, Switzerland). Amplifiable DNA contents of each tick pool were evaluated by a TaqMan realtime PCR for the 18S rRNA gene, as reported [9]. DNA samples were stored at $-80^{\circ} \mathrm{C}$ until molecular analysis.

The presence of Candidatus Neoehrlichia mikurensis was investigated by a multiplex TaqMan real-time PCR [8]. In brief, the assay is based on the amplification of a 16S rRNA gene fragment shared by members of the family Anaplasmataceae, and on the simultaneous usage of three specific probes to indicate positivity on the family (Anaplasmataceae), the genus ( $\mathrm{Ca}$. Neoehrlichia) and 


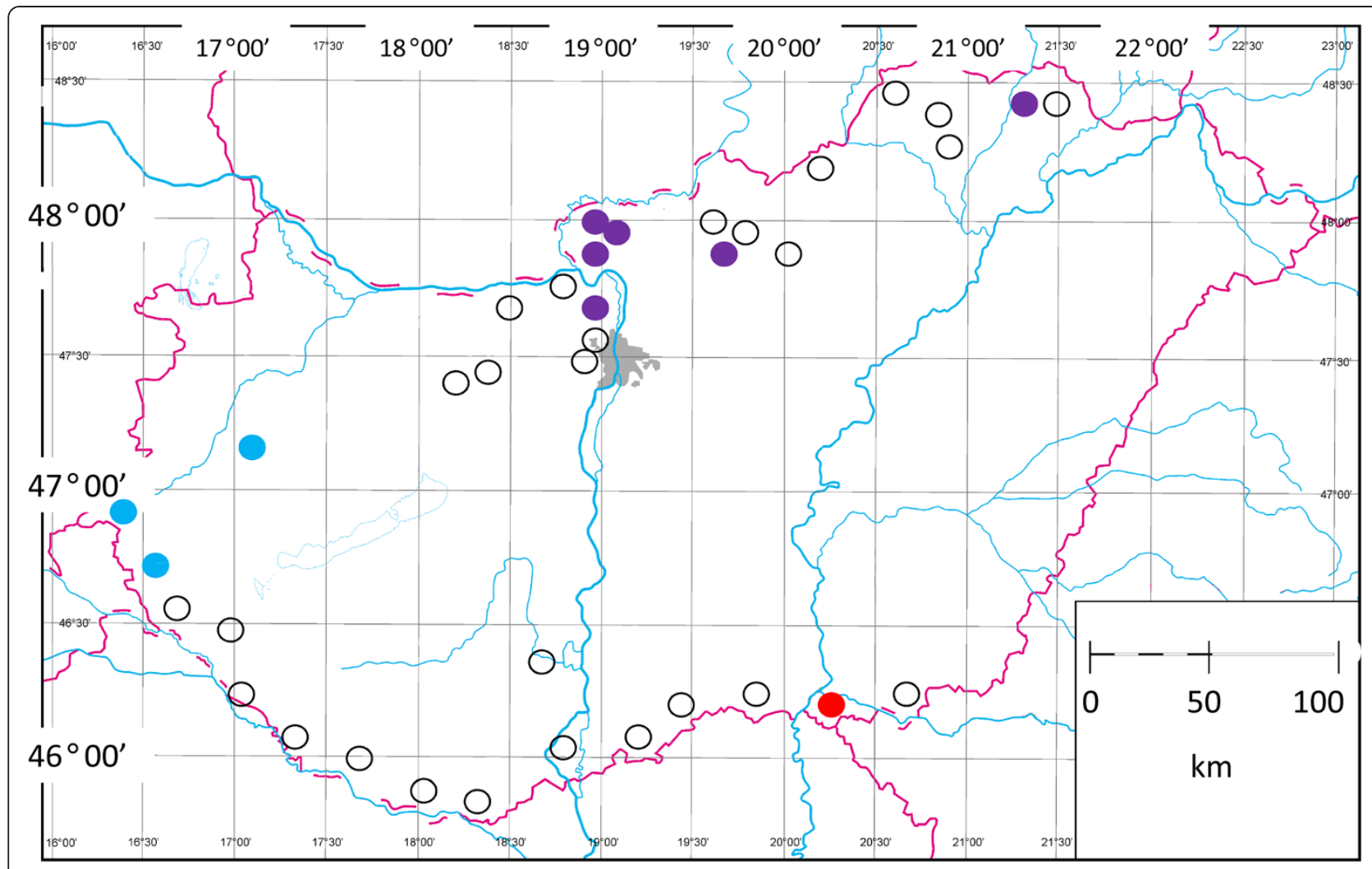

Figure 1 Places of tick collection (circles) in Hungary. Full circles indicate places with samples positive in the multiplex PCR according to the following colour codes: blue dots stand for places where only $\mathrm{Ca}$. Neoehrlichia mikurensis was identified in its genus; red dot marks the place where Ca. Neoehrlichia mikurensis was not identified, but PCR positivity was detected on the genus level (Ca. Neoehrlichia sp.); purple dots indicate places, where both types of samples were collected (i.e., some of them positive to $\mathrm{Ca}$. Neoehrlichia mikurensis and others positive to $\mathrm{Ca}$. Neoehrlichia genus excluding known European sequences of $\mathrm{Ca}$. Neoehrlichia mikurensis).

species (Ca. Neoehrlichia mikurensis) level. Each PCR run included serial 10-fold dilutions of a synthetically produced 586 bp long gene $\left(G^{2}\right.$ eneArt ${ }^{\circ}$ Strings $^{\text {Th }}$ DNA Fragments, Life Technologies, Paisley, UK) based on the sequence deposited in the GenBank [GQ501090], with known copy numbers for quantification.

$\mathrm{Ca}$. Neoehrlichia mikurensis was detected in nine out of 37 places (Figure 1). Based on the geographical distribution of positive tick pools three endemic regions of $\mathrm{Ca}$. Neoehrlichia mikurensis could be recognized in Hungary (Figure 1). Interestingly, ticks from seven places gave positive results in the $\mathrm{Ca}$. Neoehrlichia genus PCR, but were negative in the $\mathrm{Ca}$. Neoehrlichia mikurensisspecific assay. None of these places was located in Western Hungary, and in six out of seven $\mathrm{Ca}$. Neoehrlichia mikurensis was also identified (Figure 1). The maximum copy number in these samples was $2.8 \times 10^{3}$ (threshold cycle value 29), which was not enough for sequencing.

This is the first evidence of $\mathrm{Ca}$. Neoehrlichia mikurensis in Hungary. Additionally, with the exception of an endemic focus in Slovakia [10], no information is available on the occurrence of this zoonotic pathogen in neighbouring countries, highlighting the importance of the present findings in connection with Austria and Slovenia. Ca. Neoehrlichia mikurensis has been reported in geographically close regions of various countries, like Belgium and The Netherlands [2], Sweden and Denmark $[11,12]$, or Eastern-Switzerland and North Italy $[7,8]$. In this study three endemic regions of $\mathrm{Ca}$. Neoehrlichia mikurensis were recognized along the borders of Hungary. In particular, the central endemic zone $\left(48^{\circ} \mathrm{N}, 19^{\circ} \mathrm{E}\right)$ is situated within $60 \mathrm{~km}$ of the central Slovakian focus of $\mathrm{Ca}$. Neoehrlichia mikurensis (Malá Lehota [10]), therefore they may be confluent (i.e., representing a single, transboundary endemic focus).

There were pools positive in the genus-specific PCR, but negative for $\mathrm{Ca}$. Neoehrlichia mikurensis. This phenomenon was not observed previously when testing a similar number of tick specimens from Switzerland during the development of the method used in this study [8]. Taking into account the design of the genus- and species-specific probes, these results may indicate the existence of new sequevars of $C a$. Neoehrlichia spp. [8], formerly not detected in Europe. 


\section{Competing interests}

The authors declare that they have no competing interests.

\section{Authors' contributions}

SH collected the ticks, extracted the DNA, and has written the manuscript. MM designed, and in part performed the molecular analyses. EG performed most of the molecular analyses. RHL initiated and supervised the study. All authors read and approved the final version of the manuscript.

\section{Acknowledgements}

Sándor Hornok was supported by the János Bolyai Research Scholarship of the Hungarian Academy of Sciences. Molecular biology work was performed using the logistics of the Center for Clinical Studies at the Vetsuisse Faculty of the University of Zurich.

\section{Author details}

'Department of Parasitology and Zoology, Faculty of Veterinary Science, Szent István University, Budapest 1078, Hungary. ${ }^{2}$ Clinical Laboratory, Vetsuisse Faculty, University of Zurich, Zurich 8057, Switzerland.

Received: 8 July 2013 Accepted: 9 September 2013

Published: 17 September 2013

\section{References}

1. Kawahara M, Rikihisa Y, Isogai E, Takahashi M, Misumi H, Suto C, Shibata S, Zhang C, Tsuji M: Ultrastructure and phylogenetic analysis of 'Candidatus Neoehrlichia mikurensis' in the family Anaplasmataceae, isolated from wild rats and found in Ixodes ovatus ticks. Int I Syst Evol Microbiol 2004, 54:1837-1843.

2. Jahfari S, Fonville M, Hengeveld P, Reusken C, Scholte EJ, Takken W, Heyman P, Medlock J, Heylen D, Kleve J, Sprong H: Prevalence of Neoehrlichia mikurensis in ticks and rodents from North-west Europe. Parasit Vectors 2012, 5:74

3. Silaghi C, Woll D, Mahling M, Pfister K, Pfeffer M: Candidatus Neoehrlichia mikurensis in rodents in an area with sympatric existence of the hard ticks Ixodes ricinus and Dermacentor reticulatus, Germany. Parasit Vectors 2012, 5:285.

4. von Loewenich FD, Geissdörfer W, Disqué C, Matten J, Schett G, Sakka SG, Bogdan C: Detection of "Candidatus Neoehrlichia mikurensis" in two patients with severe febrile illnesses: evidence for a European sequence variant. J Clin Microbiol 2010, 48:2630-2635.

5. Diniz PP, Schulz BS, Hartmann K, Breitschwerdt EB: "Candidatus Neoehrlichia mikurensis" infection in a dog from Germany. J Clin Microbiol 2011, 49:2059-2062.

6. Schouls LM, Van De Pol I, Rijpkema SG, Schot CS: Detection and identification of Ehrlichia, Borrelia burgdorferi sensu lato, and Bartonella species in Dutch Ixodes ricinus ticks. J Clin Microbiol 1999, 37:2215-2222.

7. Koutaro M, Santos AS, Dumler JS, Brouqui P: Distribution of 'Ehrlichia walkeri' in Ixodes ricinus (Acari: Ixodidae) from the northern part of Italy. $J$ Med Entomol 2005, 42:82-85.

8. Maurer FP, Keller PM, Beuret C, Joha C, Achermann Y, Gubler J, Bircher D, Karrer U, Fehr J, Zimmerli L, Bloemberg GV: Close geographic association of human neoehrlichiosis and tick populations carrying "Candidatus Neoehrlichia mikurensis" in eastern Switzerland. J Clin Microbiol 2013, 51:169-176.

9. Boretti FS, Perreten A, Meli ML, Cattori V, Willi B, Wengi N, Hornok S, Honegger $\mathrm{H}$, Hegglin D, Woelfel R, Reusch CE, Lutz H, Hofmann-Lehmann R: Molecular Investigations of Rickettsia helvetica infection in dogs, foxes, humans, and Ixodes ticks. Appl Environ Microbiol 2009, 75:3230-3237.

10. Spitalská E, Boldis V, Kostanová Z, Kocianová E, Stefanidesová K: Incidence of various tick-borne microorganisms in rodents and ticks of central Slovakia. Acta Virol 2008, 52:175-179.
11. Andersson M, Råberg L: Wild rodents and novel human pathogen Candidatus Neoehrlichia mikurensis, Southern Sweden. Emerg Infect Dis 2011, 17:1716-1718.

12. Fertner ME, Mølbak L, Boye Pihl TP, Fomsgaard A, Bødker R: First detection of tick-borne "Candidatus Neoehrlichia mikurensis" in Denmark 2011. Euro Surveill 2012, 17:20096.

doi:10.1186/1756-3305-6-267

Cite this article as: Hornok et al:: First evidence of Candidatus Neoehrlichia mikurensis in Hungary. Parasites \& Vectors 2013 6:267.

\section{Submit your next manuscript to BioMed Central and take full advantage of:}

- Convenient online submission

- Thorough peer review

- No space constraints or color figure charges

- Immediate publication on acceptance

- Inclusion in PubMed, CAS, Scopus and Google Scholar

- Research which is freely available for redistribution

Submit your manuscript at www.biomedcentral.com/submit 